\title{
DEVELOPMENT AND PERFORMANCE EVALUATION OF ELECTRICAL MOTOR OPERATED MILK CHURNER
}

\author{
Tamrat Lema (MSc) \\ Ethiopian Institute of Agricultural Research, \\ Agricultural Engineering Research, Melkassa \\ Agricultural Research Center.P.O.Box 436, \\ Adama, Ethiopia \\ Tamrat Lema Associate Researcher
}

\author{
Eyob Hailu (BSc) \\ Ethiopian Institute of Agricultural Research, \\ Agricultural Engineering Research, Melkassa \\ Agricultural Research Center.P.O.Box 436, \\ Adama, Ethiopia \\ Eyob Hailu Assistant Researcher II
}

\begin{abstract}
Dairy industry is one of the major industries in Ethiopia which can improve the livelihood of the farmer. Butter making process is the one and the most tedious and time consuming operations in dairy industry especially for small holder farmers. It can be made by churning either cream or soar milk. Depend on acidity of the soar, churning temperature and churn speed, $20-22$ litter of soar milk required to obtain a $\mathrm{kg}$ of butter. The churning takes place in various traditional vessels including gourds and clay pots, and it takes more than two hours for butter to form. Considering the above stated problem, an attempt has been made to develop motorized milk churner machine by agricultural engineering directorate of Ethiopian agricultural research institute and performance evaluation was conducted in two regions (Adami-Tulu and Melkassa) with an objective of developing and evaluating churning equipment. The materials selected for fabrication will not contaminate the extracted butter. The machine is powered by a 1 hp speed electric motor. The prototype was developed with capacity of 40litters and its overall weight including motor is $34 \mathrm{~kg}$. The results showed the highest and lowest butter yield recorded during the tests ware $58.90 \mathrm{gm} / \mathrm{lit}$ and $50.76 \mathrm{gm} / \mathrm{lit}$ respectively. That means around 20 liters of yogurt is required to get a kilogram of butter. The results also reveal that the time taken to churn butter using electric motor operated butter churn ranges from 15 to 25 minuteswhich is depend onthe amount of milk to be churn, churning temperature and churning speed. Therefore; the improved motorized milk churner were found to obtain a high yield and good quality of butter with in short period of time and the
\end{abstract}

machine will be recommended for further scaling up works.

Keywords: Milk Churner, Churning efficiency, Clay pots, Butter.

\section{INTRODUCTION}

Milk production and processing is an important activity of small holder farmers in Ethiopia. The country has relatively favorable climate for improved, high yielding dairy cattle breeds and regions with less animal disease-stress that make the country to have a substantial potential for dairy development. Research's indicate that, in 2015/16 Ethiopia had around 11.33 million heads milkingcows (CSA, 2015/16) and in 2014/2015 fiscal year, 3.07 billion liters of cow milk were produced (CSA, 2015b).

Considering such a potential, investing in development interventions to the dairy sector will contribute to poverty alleviation in the country by increasing the income of smallholder dairy producers and creating employment (Ahmed, et al and Y. Assefa, 2004). Milk provides relatively quick returns for small-scale livestock keepers and smallholders produce the vast majority of milk in most developing countries. It is a balanced nutritious food and is a key element in household food security.

Milk contains many different components like water, fat, protein, lactose and ash. Butterfat is one of the most valued components of milk. The primary use of fresh whole milk is for home consumption followed by sale to urban centers and for fermentation to process it into butter (Felleke, G., M. Woldearegay and G. Haile, 2010). The demand of butter is 


\section{International Journal of Engineering Applied Sciences and Technology, 2020 \\ Vol. 5, Issue 4, ISSN No. 2455-2143, Pages 641-647 \\ Published Online August 2020 in IJEAST (http://www.ijeast.com)}

increases day by day though out the world. In 2018, annual butter production of the world was estimated to be 843 thousand tonnes (FAO, 2019).

Dairy processing plants are few in numbers, much of the milk produced by rural small holders is processed on farm using traditional technologies and milk processing is based on sour milk (Getachew, F., 2003). Because of this and less effort was made so far to promote simple, improved processing technologies suitable for small-scale producers the production of butter in Ethiopia is very low.

In butter making process women plays a major role. In most of cases, churning of butter is regarded as women's duty. In Ethiopia butter is extracted from yogurt and the churning takes place in various traditional vessels including gourds and clay pots. That equipment'sare not efficient either in their butter production or in saving time and labor. Studies indicated that the traditional method of churning is time consuming, perhaps, taking more than an hour (O conner et al 1993, Feyisa et al, 2009 and Yilma Z et al 2007).O'Connor et al (1993) reported that in onfarm trails in the Debre-Birhan areas, Ethiopia, an average churning time of 139 minutes. Likewise, Yilma Z et al (2007) reported 191 minutes for traditional clay pot churner while Feyisa et al (2009) reported $65 \mathrm{~min}$ on average when using the traditional clay pot churners in central rift valley areas of the country. So, the process takes one to four hours depend upon the size and type of jar, environmental condition and quantity of yogurt.

One important reason for the low output of butter is women's lesser access to improved tools and equipment. To overcome the above problems Agricultural Engineering Research Directorate (AERD) of EIAR has developed different technologies to increase butter production. So far the directorate has developed, demonstrated and distributed simple and manual operated milk churner. Working capacity of the machine is $20-25$ litters and it weight $15 \mathrm{~kg}$. Even though the churner is easy to use, assemble and disassemble its churning capacity and efficiency is low as the demand required. More or less this machine is important for farmers who have few number of milking cow and no electricity access.

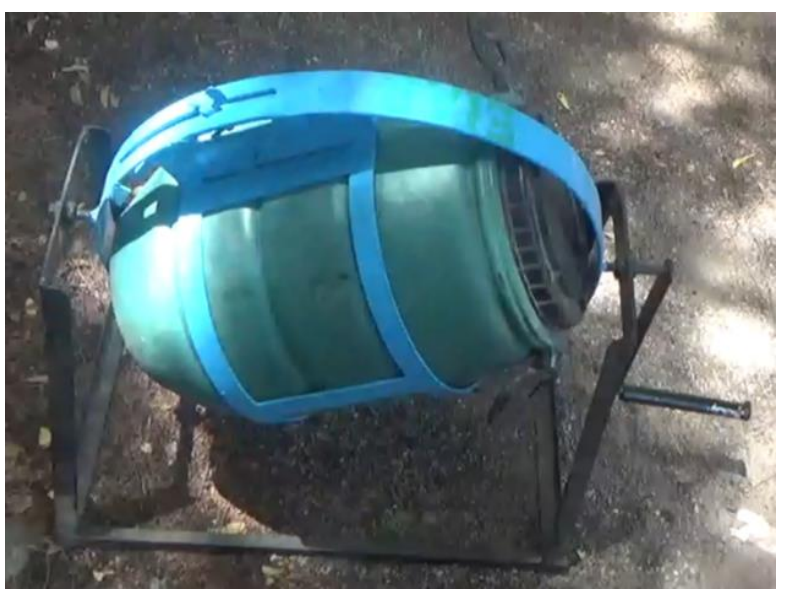

Fig. 1 Manual operated milk churner

To tackle the limitation of manual operated milk churner and to enhance butter production the directorate has considered developinga butter churner with high churning capacity and efficiency. Therefore, this research activity was proposed to reduces the work load, improves hygiene, easy to operate and handle for those who engaged with butter production in urban and semi urban area of the countrybecause the churn requires electric power to operate.

\section{OBJECTIVE}

- To developelectric motor operated butter churn.

- To evaluate performance of electric motor operated butter churn.

- To reduce time spent and women farmers work load in churning activity.

\section{MATERIAL AND METHODS}

\subsection{Description of the churn}

The developed electric motor operated butter churn consists of hopper, hopper lid, bearings, shaft, blade/beater, pulley, belt and handle (optional). The material of the prototype was selected by considering toxicity for food, weight and cost. Hence, almost all parts of the machine made from aluminum. The total weight of the churn with full accessory is $34 \mathrm{~kg}$ but the motor by itself takes $15 \mathrm{~kg}$ of the total weight. The machine was designed with churning capacity of 40 litters of sour milk (Irgo). Most of the time it works with the help of electric power but at the time of power goes off the operator can continue his/her work by using handle. 
International Journal of Engineering Applied Sciences and Technology, 2020

Vol. 5, Issue 4, ISSN No. 2455-2143, Pages 641-647

Published Online August 2020 in IJEAST (http://www.ijeast.com)

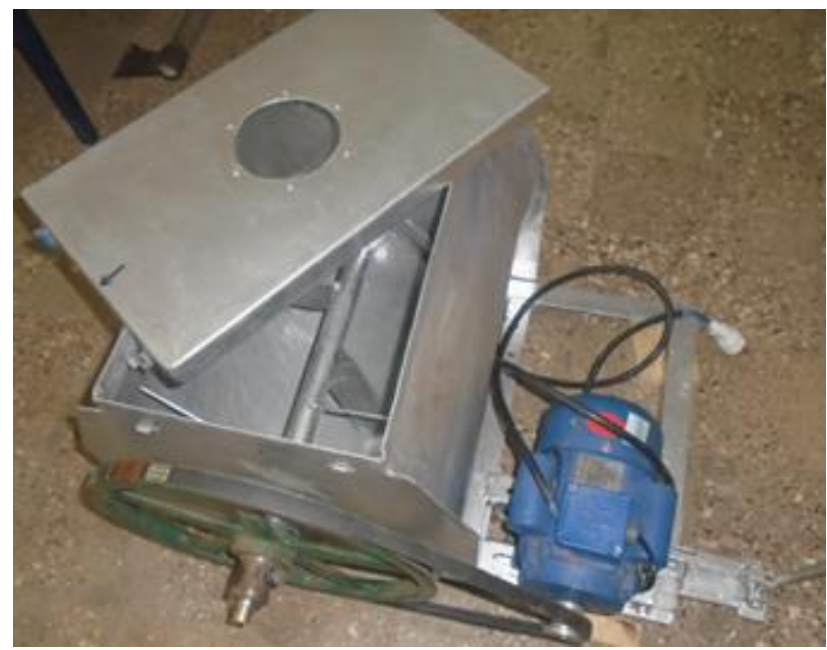

Fig. 2Electric motor operated milk churner

\subsection{Working principle of the machine}

Initially, depending on climatic condition milk is stored in storage utensil for two to three days to make yogurt. Before start the operation, the churn positioned at the desired place near to socket outlet; then the sour milk poured into the hopper. After checking the tightness of the belt, the socket plugs in to socket outlet so that the motor start working and the rotational movement of the motor transferred to the shaft through belt and pulley. Blades fixed on the periphery of the horizontal shaft ensure maximum mixing and rotation of yogurt. Due to turbulence movement of sour milk butter grain will be formed. The formation ofgranules inspected through eyeglass occurred at the center of hopper lid. Finally butter grain will be collected by hand from the surface of hopper, blades and floating on the surface of yogurt liquid. The process takes $15-25$ minutes depend on the temperature, humidity, quality and quantity of yogurt.

\subsection{Design and fabrication of the churn}

The machine was developed with functional drawing using inventory software and some part of the machine fabricated at AIRIC workshop but due to absence of aluminum welding machine in the workshop welding was done outside. The side view and front view drawings of developed machine including the shaft and blade arrangement are shown in figure below. During the design weight and easiness of the machine to operate and transport, simplicity in construction, lower cost of production and stability when in use were considered.
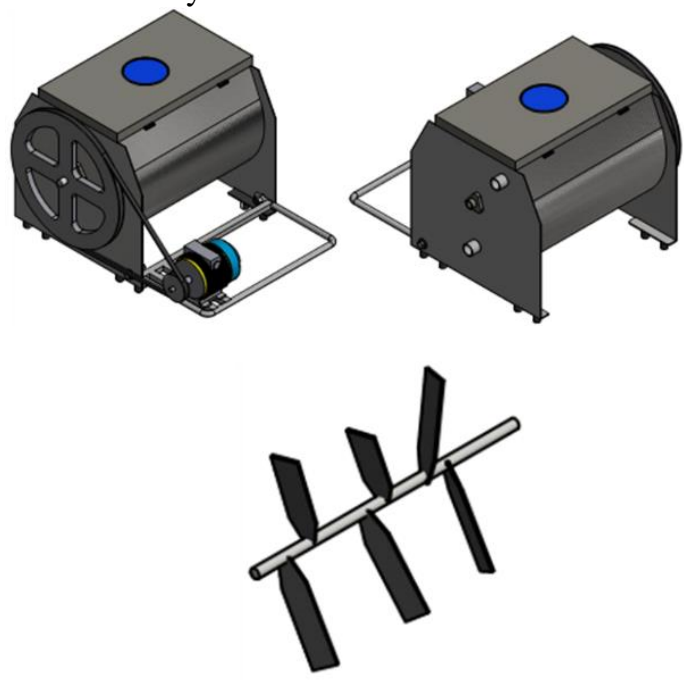

Fig. 1 Pictorial view of the machine

\subsubsection{Selection of materials}

Selection of proper materials for designing and manufacturing of various components the machine of was very important. The materials used for constructing the prototype is listed on table 1 which are easily available on the market and free from toxicity for food. The construction materials were light but durable andalso optimum in cost.

Table 1.Materials of different components of the machine 
International Journal of Engineering Applied Sciences and Technology, 2020

Vol. 5, Issue 4, ISSN No. 2455-2143, Pages 641-647

Published Online August 2020 in IJEAST (http://www.ijeast.com)

\begin{tabular}{|c|c|c|c|c|}
\hline \multicolumn{5}{|c|}{ PARTS LIST } \\
\hline ITEM & QTY & \multicolumn{2}{|r|}{ PART NUMBER } & DESCRIP \\
\hline 1 & 1 & \multicolumn{2}{|c|}{ contanier 1} & aluminium \\
\hline 2 & 1 & \multicolumn{2}{|c|}{ side cover new } & aluminium \\
\hline 3 & 1 & \multicolumn{2}{|c|}{ SIDE cover 2} & aluminium \\
\hline 4 & 2 & \multicolumn{2}{|c|}{ bearrring } & stainless steel \\
\hline 5 & 1 & \multicolumn{2}{|c|}{ motor seat new } & mild steel \\
\hline 6 & 1 & \multicolumn{2}{|c|}{ container } & aluminium \\
\hline 7 & 1 & \multicolumn{2}{|c|}{ motor ass } & mild steel \\
\hline 8 & 1 & \multicolumn{2}{|c|}{ motor shafttt } & stainless steel \\
\hline 9 & 1 & \multicolumn{2}{|c|}{ display } & glass \\
\hline 10 & 1 & \multicolumn{2}{|c|}{$\begin{array}{l}\text { ANSI B18.2.3.4M-M14 } \\
\times 2 \times 30\end{array}$} & mild steel \\
\hline 11 & 1 & \multicolumn{2}{|c|}{$\begin{array}{l}\text { ANSI B18.2.3.4M-M14 } \\
\times 2 \times 50\end{array}$} & mild steel \\
\hline 12 & 2 & \multicolumn{2}{|c|}{$\begin{array}{l}\text { ANSI B18.2.4.2M- } \\
\text { M14×2 - } 21\end{array}$} & mild steel \\
\hline 13 & 1 & \multicolumn{2}{|c|}{ blade ass } & aluminuim \\
\hline 14 & 1 & \multicolumn{2}{|c|}{ V-Belt transmission2 } & \\
\hline $\begin{array}{l}\text { Dram by } \\
\text { Eyob Hallu }\end{array}$ & $\begin{array}{l}\text { Chedied by } \\
\text { Tamrat L. }\end{array}$ & $\begin{array}{l}\text { Approved by } \\
\text { AERDD }\end{array}$ & & \begin{tabular}{|l|} 
Date \\
Jul,2018
\end{tabular} \\
\hline \multirow{2}{*}{\multicolumn{3}{|c|}{$\begin{array}{l}\text { AGRICULTURAL ENGINEERING } \\
\text { RESEARCH DIRECTORATE }\end{array}$}} & \multicolumn{2}{|c|}{ Motorized elctric chumel } \\
\hline & & & 01 & $\begin{array}{l}\text { scake } \\
1: 1\end{array}$ \\
\hline
\end{tabular}

\subsubsection{Design components of the machine}

\subsubsection{Shaft design}

The shaft was made of circular cross-section and was solid. It is subjected to torsion, axial tension, bending and compression or to acombination of any or all of these actions of failure loads shocks and stress concentration. The shaft was selected based on considerations such as high strength, lownotch sensitivity, ability to be heat treated and good machinability. The diameter ofthe shaft was $33 \mathrm{~mm}$.

\subsubsection{Design oftorque for shaft}

Torque on the shaft was calculated using formula: (khurmi and Gupta, 2005).

$$
T=\frac{\pi \times \tau \times d^{2}}{16}
$$

$(\mathrm{Nm})$

$$
\mathrm{T}=\text { torque transmitted by the shaft }
$$

$\tau=$ allowable shear stress $\left(\mathrm{N} / \mathrm{mm}^{2}\right)$

$$
\mathrm{d}=\text { diameter of the shaft }(\mathrm{mm}) \text {. }
$$

With the values of allowable shear stress as $8 \mathrm{~N} / \mathrm{mm}^{2}$ and diameter of the shaft $33 \mathrm{~mm}$, the torque was calculated using the above equation which $56.45 \mathrm{Nm}$.

\subsubsection{Design of power for shaft}

The power on the shaft wasdetermined from the following expression: (khurmi and Gupta, 2005)

$\mathrm{P}=\mathrm{T} \times \omega$

$$
\begin{aligned}
& \mathrm{P}=\text { Power transmitted by the shaft }(\mathrm{W}) \\
& \mathrm{T}=\text { Torque transmitted by the shaft }(\mathrm{Nm}) \\
& \omega=\text { Is the angular velocity }
\end{aligned}
$$

$$
\text { But, } \omega=\frac{2 \times \pi \times N}{60}
$$

$$
\mathrm{N}=\mathrm{rpm} \text { of the shaft }
$$

The power transmitted for the maximum rpm $(90 \mathrm{rpm}$ ) was calculated $532.029 \mathrm{~W}$ or $0.53 \mathrm{KW}$ or $0.76 \mathrm{hp} \approx$ $1 \mathrm{hp}$

\subsubsection{Design of belt length}

The length of the beltwas calculated based on the following formula: (Sharma,2010)

$$
L=2 C+\pi \frac{\left[D_{R}+D_{N}\right]}{2}+\frac{\left(D_{R}-D_{N}\right)^{2}}{4 C}
$$

$\mathrm{L}=$ Length of belt, $\mathrm{mm}$

$\mathrm{C}=$ center to center distance $\mathrm{b} / \mathrm{n}$

pulleys, $\mathrm{mm}$ driven with $D_{R}>D_{N}, m m$

$D_{R}$ and $D_{N}$ diameters of driver and

$$
\begin{array}{ll}
\text { Since } & C=390 \mathrm{~mm} \\
& D_{R}=400 \mathrm{~mm} \\
& D_{N}=50 \mathrm{~mm}
\end{array}
$$

The designed belt length was $=158 \mathrm{~mm}$

\subsection{Performance test of the machine}

To check whether the machine was functionally acceptable or not, a preliminary test run wasundertaken. During laboratoryexperimentssmall plastic bags, weight balance (0.1gm accuracy), plastic container, sour milk/yogurts, lactometer, acidity tester, graduating cylinder and stop watch instruments, were employed. The prototype churner had good stability in terms of operation and performed the required job acceptably. After this laboratory tests, overall performance of them achine were carried out at Melkassa Agricultural Research Center (MARC) and Adami-Tulu Agricultural Research Center (AARC).

Preliminary test was carried out at different churn speed and churning temperature. Many parameters were recorded during the test whichincludes the amount of soar/fermented milk used, acidity level of 
yogurt, purity of soar, starting time of churning, ending time of churning, time taken to churn and butter yield were collected.

\subsection{Data analysis}

The data obtained during laboratory test were analyzed using Excel worksheet.

\section{RESULTS AND DISCUSSION}

After fabrication of electric motor operated butter churn parts were coupled and taken to the laboratory. So, the results of the test were indicated below is based on the performance result of the machine conducted in laboratory. Milk from both crossbred and local cows was used for evaluations of the milk churner. The capacity of the improved churners distributed was 40 liters. Nonetheless, the amount of soar milk used for the evaluation of milk churner was not more than 25 liters. The following table shows the results of the evaluation based on the data gathered from the laboratory. In fact efficiency of butter making is markedly influenced by churn speed, temperature and acidity of the sour milk.

Table 2.Performance result of electric motor operated butter churn

\begin{tabular}{|c|c|c|c|c|c|c|c|c|}
\hline \multirow{3}{*}{$\begin{array}{l}\text { Parameters were } \\
\text { considered during } \\
\text { the test }\end{array}$} & \multicolumn{8}{|c|}{ Performance result of electric motor operated butter churn } \\
\hline & \multicolumn{4}{|c|}{$\begin{array}{c}\text { Local cow } \\
\text { (At Adami Tulu) }\end{array}$} & \multicolumn{4}{|c|}{$\begin{array}{c}50 \% \text { Crossbred cow } \\
\text { (At Melkassa) }\end{array}$} \\
\hline & Trial1 & Trial2 & Trial3 & Trial4 & Trial1 & Trial2 & Trial3 & Trial4 \\
\hline Acidity(PH) levels & 3.6 & 3.4 & 3.7 & 3.5 & 3.4 & 3.4 & 3.6 & 3.8 \\
\hline Lactometer reading & 25 & 25 & 25 & 23 & 25 & 25 & 25 & 25 \\
\hline $\begin{array}{c}\text { Churning } \\
\text { temperature }\left({ }^{\circ} \mathrm{c}\right)\end{array}$ & 24 & 23.5 & 25.7 & 21.9 & 22.4 & 24 & 26 & 28.8 \\
\hline $\begin{array}{c}\text { Churning humidity } \\
(\%)\end{array}$ & 44 & 44 & 45 & 42 & 42 & 42 & 43 & 44 \\
\hline $\begin{array}{l}\text { Amount of soar to be } \\
\text { churn (lit) }\end{array}$ & 25 & 25 & 16 & 14.5 & 20 & 20 & 17 & 25 \\
\hline $\begin{array}{l}\text { Churning speed } \\
\text { (rpm) }\end{array}$ & 192 & 192 & 160 & 180 & 160 & 160 & 180 & 180 \\
\hline Churning time $(\min )$ & 20 & 22 & 20 & 25 & 15 & 17 & 20 & 20.42 \\
\hline Butter yield (gm) & 1298.5 & 1371.75 & 884 & 854.05 & 1140 & 1115 & 999.94 & 1269 \\
\hline Butter yield (gm/lit) & 51.94 & 54.87 & 55.25 & 58.90 & 57 & 55.75 & 58.82 & 50.76 \\
\hline
\end{tabular}

The observed results indicated that the yields of butter obtained from preliminary tests were varied with acidity of soar, churning temperature and churn speed. The highest and lowest butter yield recorded during the tests was $58.90 \mathrm{gm} / \mathrm{lit}$ and $50.76 \mathrm{gm} / \mathrm{lit}$ respectively. That means 20 liters of yogurt is required to get a kilogram of butter. Research reported that butter-fat is present in milk in low concentration of $3.2-5.5$ percent depending on the breed (SHIV,2007). This clearly indicated thattheresult obtained from the test lies on recommended interval.

Laboratory test results also reveal that the time taken to churn butter using electric motor operated butter churn ranges from 15 to 25 minutes. In fact the churning time is affected by the amount of milk to be churn, churning temperature and churning speed. If the temperature is too high, the yield of butter is reduced because a large proportion of the fat remains in the buttermilk, and the butter will be spongy and of poor quality. On the other hand if the temperature is 
too low, the time taken to churn is too high because it takes longer time to break butter gain or globules.

Furthermorethe amount of soar to be churn had an impact on the performance of the machine. As shown on the above table the amount butter yield extracted from younger was deceasing when the amount of soar deviate from the mean holding capacity of the churner and the operation took longer time. Feyisa et.al.2009 also reported that filling more than half of the volumetric capacity of the improved milk churner increases churning time.

The performance of the machine was evaluated by varying the operating speeds at 160, 180 and $192 \mathrm{rpm}$ by changing driven pulley diameter. These speeds were measured with a tachometer to ensure an accurate speed output.Results reveal that optimum machine performance produces $58.90 \mathrm{gm}$ of butter from a liter of soar milk at an operating speed and extraction time of $180 \mathrm{rpm}$ and 25 minutes respectively. The quantity of butter extracted was found to be dependent on the operating speed of the extractor and the extraction time.

\section{CONCLUSION AND RECOMMENDATION}

\subsection{Conclusion}

A motorized milk churner was developed and itsperformance evaluated. The machine is easy tooperate, serviceable and maintainable. Thematerials selected for fabrication will notcontaminate the extracted butter. The machine is powered by a $1 \mathrm{hp}$ speed electric motor. The highest and lowest butter yield recorded during the tests was $58.90 \mathrm{gm} / \mathrm{lit}$ and $50.76 \mathrm{gm} / \mathrm{lit}$ respectively at an operating speed and churning time of 180:25 and 180:20.42 respectively. The machine can be used for small and medium scale milk production to encourage butter production in Ethiopia because; it is extremely time and cost effective and affordable for village. It is possible a group of women could share in the purchase of a single milk churning machine.

\subsection{Recommendation}

It is recommended that the butter extracted from thismachine be subjected to other tests as related tonutrition. It is highly recommended to train local artisans to manufacture, repair and maintain the machine. Since this simple electric machine will be very useful by local women and butter producers the machine will be recommended for further scaling up works.

\section{ACKNOWLEDGEMENT}

Next to the almighty God, the majority of my gratitude is to Ethiopian Agricultural Research Institute for financing this research and Melkassa Agricultural Research Center for giving mechance to pursue the studies.

I am also thankful to Adami-Tulu Agricultural Research Institute for all their help from the beginning to the very end by facilitating laboratory and giving the required amount of sour milk. I would like to extend my thanksto staff of Agricultural Engineering department of Melkassa Agricultural Research Center (MARC), especially to Mr. Fitsum Abebe, Mr. Meseret Abebe, Mr. Dereje Alemu, Mr. Teferi Getahun, Mr. Dereje Yihun, and Mr. Maney Ayalew, for their indispensable advice and assistances during the research work.

\section{REFERENCES}

1 Ahmed, M.A.M., S. Ehui and Y. Assefa, (2004). Dairy development in Ethiopia. EPTD Discussion paper No. 123. International Food Policy Research Institute. Washington, U.S.A.

2 CSA.( 20014/15). Agricultural sample survey 2014/2015.Vol. II.Report on livestock and livestock characteristics.Statistical Bulletin 578. Addis Ababa, Ethiopia: CSA

3 CSA.(2015b). Agriculture sample survey 2014/2015 (2007E.C.)(Septmber-January 2014/2015), Volume VII. Report on crop and livetsock product utilization (Private peasant holdings, Meher Season). Central Statistical Agency(CSA): Addis Ababa, Ethiopia.

4 D.N. Sharma and S.Mukesh.(2010). Farm Machinery Design.Principles and Problems. JAINBROTHERS, NEew Delhi.

5 FAO. (2019). Dairy market review, Overview of global dairy market developments in 2018, March 2019

6 Felleke, G., M. Woldearegay and G. Haile, (2010). Inventory of Dairy Policy Ethiopia, Target Business Consultants Plc, Netherlands Development Organization (SNV), Addis Ababa, Ethiopia.

7 FeyisaHundessaTesfaye Lemma and EsayasAssefa. (2009). Demonstration and Evaluation of plastic made improved milk churner in Adami Tulu District of East Shewa. FRG project 2009 FRG completed research reports 2009. 
8 Getachew, F., (2003). Milk and Dairy Products, Postharvest Losses and Food Safety in SubSaharan Africa and the Near East. A Review of the Small Dairy Sector - Ethiopia.FAO Prevention of Food Losses Programme. FAO, Rome: Italy.

9 Khurmi, S.R. and Gupta, K.J. (2005).A text book of machine design.14th Edition.Pub by Eurasia publishing house PVT.LTD. Ram nagar, New Delhi-110 055.pp 509- 557.

10 O'Connor C. B., Mezgebu S and Zewdie Z. (1993).Improving the efficiency of butter making in Ethiopia. Retrieved from http://www.fao.org/docrep/V1650T/v1650T 0m.htm

11 SHIVKUMARSAIPAINKRA.(2007).Studies on milk composition of sahiwal cows in chhattisgarhhttps://pdfs.semanticscholar.org/ 43d6/88de55f1 ca96df7700e0a81806e4f5839 d5f.pdf

12 Yilma Z. Loiseau G and Faye B.(2007). Manufacturing efficiencies and microbial properties of Ethiopian milk products; butter and Ayib- Ethiopian cottage cheese. Livestock Research for Rural Development, 19(88). 